\title{
Residents' Perception of Impacts of Amansuri Conservation and Integrated Development Project (ACID) in Jomoro District, Western Region, Ghana
}

\author{
Christopher Mensah ${ }^{1}$, Oheneba A. Akyeampong ${ }^{2} \&$ Barima Kwabena Antwi ${ }^{3}$ \\ ${ }^{1}$ Department of Hospitality and Tourism Management, Ho Polytechnic; the Department of Hospitality and \\ Tourism Management, University of Cape Coast, Ghana \\ ${ }^{2}$ Hospitality and Tourism Management, University of Cape Coast, Ghana \\ ${ }^{3}$ Department of Geography and Regional Planning, University of Cape Coast, Ghana \\ Correspondence: Christopher Mensah, the Department of Hospitality and Tourism Management, Ho Polytechnic, \\ Ho, Volta Region, Ghana, West Africa. Tel: 233-244-653-941. E-mail: narhyo@yahoo.co.uk
}

Received: February 12, 2013 Accepted: April 5, 2013 Online Published: April 16, 2013

doi:10.5539/jsd.v6n5p73 URL: http://dx.doi.org/10.5539/jsd.v6n5p73

\begin{abstract}
The impacts of Community-based natural resource management (CBNRM) projects are rarely independently evaluated through well-designed studies and only a few studies have employed the sustainable livelihood. This study used interviews and focus group discussions with local residents in three project communities within a framework of qualitative research design to examine the impact of Amansuri Conservation and Integrated Development Project (ACID) in Ghana on the five livelihood assets of local residents. Results from the study show that the ACID project has led to improved income generation, employment opportunities and natural resource conservation in the communities. Some level of success has also been attained in the area of conservation through the establishment of a community nature reserve, while majority of the residents have also changed their attitude towards natural resource use and management largely because of motivation from the direct benefits.
\end{abstract}

Keywords: Ghana, community-based, natural-resource-management, sustainable-livelihood, conservation

\section{Introduction}

The traditional approach to conserving natural resources has been through the protected area (PAs) management systems which are found in almost every country. Whereas advocates argue that PAs constitute the most appropriate strategy to conservation, opponents contend that protected area management systems have proved inadequate in ensuring sustainable utilisation of natural resources (Barrow \& Fabricius, 2002). PAs have been characterised by constant conflict between local communities and park managers (Madden, 2006) especially in developing countries.

In order to give conservation a human-face, people-oriented conservation methods crept into conservation narratives in the 1980s and 1990s. One approach is community-based natural resource management (CBNRM). It is a process whereby local people and communities organise themselves to play a central role in identifying development priorities linked to the sustainable management of their natural resources (World Bank, 1995). This approach aims at meeting conservation and development goals of people whose livelihoods depend on natural resources. Its appeal in sub-Sahara Africa, especially in East and Southern Africa, has been phenomenal. Projects such as Communal Area Management Programme for Indigenous Resources (CAMPFIRE) in Zimbabwe, and Administrative Design for Game Management Areas (ADMADE) in Zambia are well known examples and have motivated other programmes in Africa (Newman \& Webster, 1993, cited in Bandyopadhyay et al., 2004).

The ability of CBNRM projects to achieve their objectives has been questioned since its enthusiastic inception in the 1980s. Some communities where CBNRM projects were implemented have experienced depletion of vital natural resources as well as persistent and unbearable effects of poverty (Nkata \& Breen, 2010). Critics argue that the approach has been ineffective at conserving biodiversity; it has, to them, rather created various social 
problems and resulted in a waste of financial and human resources that would have been better utilised in 'direct' support for conservation and protected area management activities (Bruner et al., 2001).

According to Gubbi et al. (2009), the impact and lasting legacy of community-based natural resource management projects are rarely independently, evaluated and, given the quantum of cost of such projects, it is extremely important to evaluate the impact of CBNRM projects with well-designed studies. Furthermore, few studies have used the sustainable livelihood framework to evaluate the impact of CBRNM projects. It is against this background that this paper seeks to assess the impact of the Amansuri Conservation and Integrated Development Project (ACID) in Ghana. The evaluation criterion is based on the five livelihood assets (i.e. human, capital, natural, social and physical) of local residents from the perspective of sustainable livelihood framework, as described below, with the view of contributing theoretical knowledge as well as empirical evidence on the implementation of CBNRM principles.

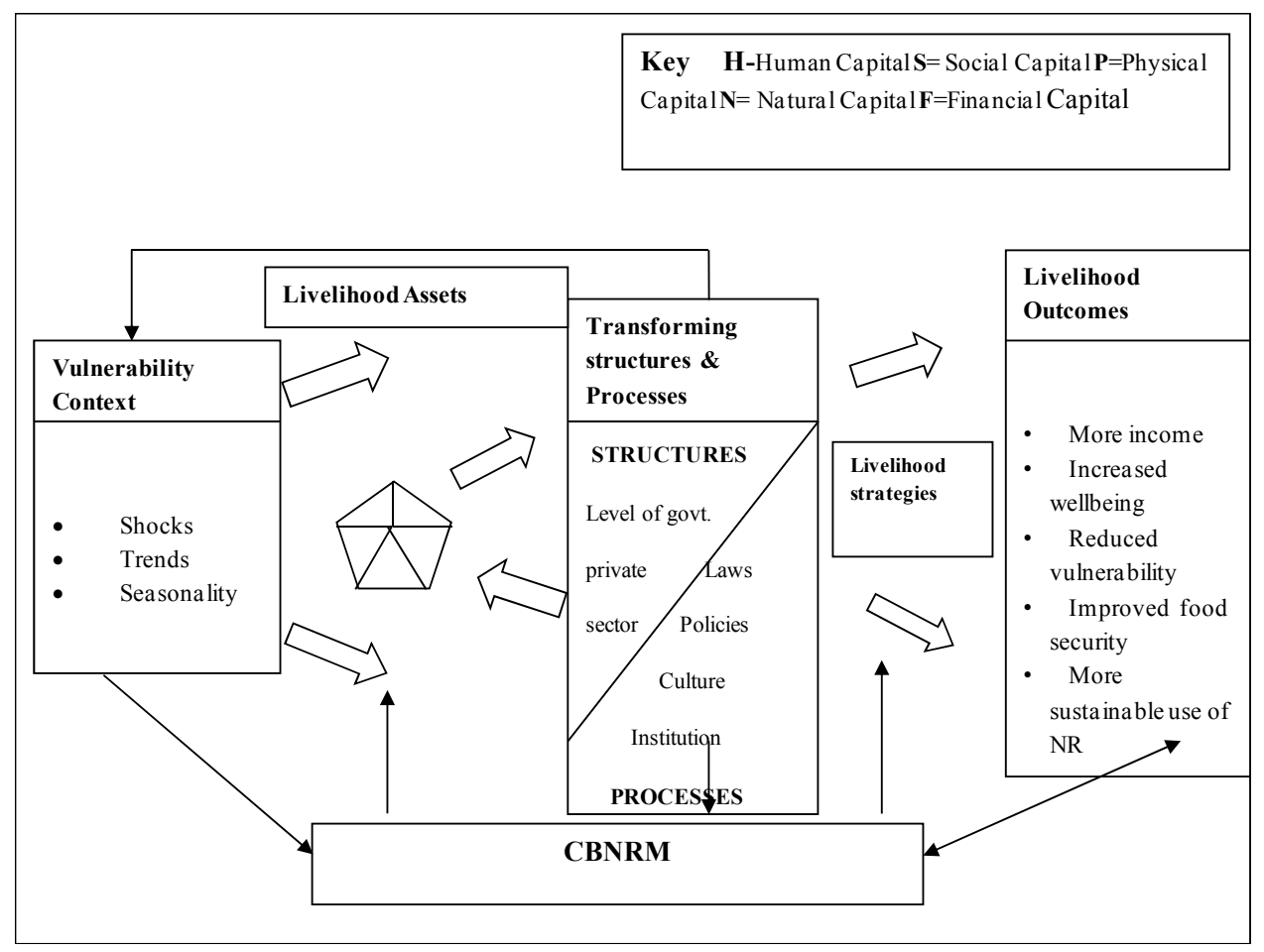

Figure 1. Livelihood framework

ACID is a CBNRM project located in the Western Nzema Traditional Area in the Jomoro District of the Western Region of Ghana (Figure 2). Launched in April 2000, the project aimed at conserving the Amansuri Wetland ecosystem while enhancing local development through the promotion of ecotourism as an appropriate land use practice compatible with sustainable natural resource use. The project envisaged the promotion of ecotourism based on the natural attraction of the area, particularly the popular silt village of Nzulezo (Ghana Wildlife Society [GWS], 1998). The project was initiated by the Chiefs and people of the Western Nzema Traditional Area and implemented through the partnership with Ghana Wildlife Society (an environmental NGO). The project involved six communities (i.e. Beyin, Nzulezo, Ngelekazo, Miegyinla, Ebonloa, and Ekabaku). The first phase of the project was financed by the Dutch Government.

\section{Literature Review}

\subsection{Community-Based Natural Resource Management (CBNRM)}

CBNRM emerged in the 1980s as a conservation approach that purports to integrate both conservation and development needs. CBNRM comprises a range of activities practised in various parts of the world, where the co-existence of community with nature is its central concept (Kumar, 2005). Nhantumbo et al. (2003) define CBNRM as a participating power sharing process aimed at giving grass-root institutions the capacity to decision-making and rights to control their resources. In the view of Leach et al. (1999), CBNRM is a process by which local groups or communities organise themselves with varying degrees of exogenous support so as to 
apply their skills and knowledge to the care of natural resources and the environment, while satisfying their livelihood needs.

The number of CBNRM projects has increased considerably over the last two decades. For example, as of 1995, $75 \%$ of World Wide Fund for Nature's (WWF) 179 forest conservation projects around the world combined social and livelihood objectives including those of biodiversity conservation (Jeanrenaud, 2002). In East Africa alone, there are 171 CBNRM projects in Kenya, Uganda and Tanzania (Barrow et al., 2000). Some of the popular CBNRM projects in Africa are: Luangwa Integrated Resource Development Project (LIRDP) in Zambia, CAMPFIRE in Zimbabwe (regarded as the first CBNRM project in the world (Newman \& Webster, 1993) and Ngorongoro Conservation Area in Tanzania (Kijazi, 1996).

A majority of CBNRM projects have evolved around existing government-managed protected areas while others are community initiated and managed conservation projects with either technical or funding support or both from NGOs and development agencies. The ACID project falls under the latter category. CBNRM projects implement a suite of programmes such as direct compensation, ecotourism development and revenue generation activities, provision of alternative income strategies, small loan programmes, agroforestry, provision of community infrastructure including schools, clinics, wells, roads, sanitation projects (Newmark \& Hough, 2000; Wells, Brandon, \& Hannah, 1992).

According to Turner (2004), the basic assumption underlying CBNRM is that local communities do not sufficiently value conservation in and of itself. Therefore, community participation without development would jeopardize conservation. CBNRM projects are also based on the presupposition that local population have a greater interest in the sustainable use of resources than does the state or distant corporate managers; that local communities are more cognisant of the intricacies of local ecological processes and practices; and that they are better able to effectively manage those resources through local or 'traditional' forms of access (Li, 2002).

\subsubsection{CBNRM: Reality or Rhetoric?}

Studies aimed at assessing the ability of CBNRM projects to achieve their goals have yielded mixed results. Hughes and Flintan (2001) catalogued a number of CBNRM projects that have led to improved livelihood and conservation conditions. For example, in Lake Mburo National Park in Uganda, project funds were used to build schools and clinics. Koziell and Inoue (2006) studied the Mamirauá Sustainable Development Reserve (MSDR) in Brazil and revealed that the ecotourism component of the project benefited the surrounding local communities through the employment of 33 residents as lodge workers and guides.

CAMPFIRE in Zimbabwe is the most often cited successful CBNRM project. For instance, elephant populations increased steadily while buffalo numbers have been maintained since the late 1980s. Additionally, poaching has been contained, to reduced levels of illegal off-take of wildlife population and fish. In the sphere of socio-economic impact, CAMPFIRE supplements incomes of households (Bond \& Frost, 2005). In 2001, about 80,000 households received cash dividends to the tune of US\$14.02 per household, and many of these households made social investments and built small household businesses. Furthermore, communities enjoy secondary benefits such as schools, clinics and community grinding mills and shops (Arntzen et al., 2003).

Nevertheless, other studies have also portrayed the benefits of CBNRM projects as inadequate, minimal and ineffective in promoting sustainable natural resource management and rural development. Barrow et al. (2000) reviewed community wildlife conservation in East Africa and concluded that the economic value of resources shared among communities was small and only few jobs are created. In Mozambique, Nhantumbo et al. (2003) concluded that any major impact of CBNRM in improving people's livelihoods of the people is still a myth as the process and pace were too slow to produce any short-term significant impact.

Further empirical evidence shows that many conservation projects being implemented with the CBNRM philosophy, and, in reality, those touted as major success stories, are experiencing problems. Problems range from lack of delivery of sufficient tangible benefits impacting significantly on people's livelihoods, to a lack of community cohesion and stable local governance (Barrow \& Fabricius, 2002). Doubts have also been expressed about CBNRM's ability to yield conservation results as critics argue that it has been ineffective at conserving biodiversity. It has resulted in a waste of financial and human resources that would have been better utilised in 'direct' support for conservation and protected area management activities (Bruner et al., 2001). Moreover, others have questioned the capacity of conservationists to implement projects with development agenda. It is seen as outside of the mandate of conservation organisations and, more properly, the role of government and rural development institutions (Jeanrenaud, 2002). 


\subsection{The Sustainable Livelihood Framework (SLF)}

The SLF (Figure 2) is a conceptual framework for analyzing causes of poverty, peoples' access to resources and their diverse livelihood activities, and relationship between relevant factors at micro, intermediate, and macro levels (Adato \& Meinzen-Dick, 2002). It provides a useful analytical structure for understanding livelihoods and summarising the main issues of enterprise impact (Ashley, 1999).

The key components of a SLF are livelihood assets, the vulnerability context, the policies, institutions and processes that affect livelihood strategies of people (positively and negatively) and, their livelihood outcomes (Long, 2004).

Assets or capital endowments: As embedded in the framework, these are the basic livelihood building blocks and consist of physical, natural, social, financial and human forms of capitals (DFID, 1999).

Physical capital is the infrastructure that is available in a given locale, e.g. roads, buildings, water supplies, equipment and transport and telecommunication facilities; natural capital refers to the biophysical elements such as water, air, soils, sunshine, woodlands, minerals, etc. These are naturally occurring assets that are largely renewable which people rely on for their livelihood; social capital relates to the range of social networks and associated links (both formal or institutional and informal) that people have access to, such as friends, family and other people who can offer support; financial capital is the money and cash investments that are available, such as savings, credits, income and migrant's remittances and access to credit; and human capital relates to existing capacity, in terms of educational attainments, knowledge base and health status of people.

Vulnerability context is a key to sustainable livelihood and it includes shocks, trends and seasonality (DFID, 1999). It can adversely affect people's assets and their choice of livelihoods, although not all vulnerabilities are negative (Shen, Hughey, \& Simmons, 2008). Policies, institutions and processes refer to the local and external (national and international) organisational, institutional and administrative structures and arrangements that affect the ability of different individuals and groups to access resources and opportunities needed to improve or simply continue practising their livelihoods.

According to Ashley (1999), livelihood strategies comprise activities which people undertake in order to attain livelihood outcomes. These include the pursuit of diverse portfolio of activities including on-farm activities, off-farm activities and migration. Livelihood outcomes are components of improved livelihoods or well-being (e.g. good health, more income, reduced vulnerability, empowerment, food security, more sustainable use of the natural resource base).

SLF has been applied in varied disciplines for different purposes. Farrington et al. (1999) used the framework to assess how CBNRM activities in Namibia affected the livelihoods of different stakeholders. Elasha et al. (2005) used it to assess the livelihood impact of climate change on the rural poor in the Sudan-Sahel region. Ashley (2000) reviewed the impact of natural resource management programmes in Namibia using the SLF. This paper purposefully examined the five livelihood assets to understand how it has impacted on the living condition of the people in the study area.

\section{Study Area and Methodology}

The ACID project area is located within the Western Nzema Traditional Area of the Jomoro District, one of the 13 administrative districts in the Western Region. It can be found in the south-western part of the Western Region of Ghana as illustrated in Figure 2. The ACID project area is about $360 \mathrm{~km}$ west of Accra, with the closest large urban centre being Axim, $50 \mathrm{~km}$ to the east. The Amansure wetland catchment area is about 929 $\mathrm{km}^{2}$ and lies on the western coastline of Ghana $\left(04^{\circ} 55^{\prime}-05^{\circ} 15^{\prime} \mathrm{N}\right.$ and Longitudes $\left.02^{\circ} 15^{\prime}-02^{\circ} 45^{\prime} \mathrm{W}\right)$. The ACID project is restricted to a portion in the Western Nzema Traditional Area, about $381 \mathrm{~km}^{2}(40 \%$ of the total catchment area). The project focussed on ecotourism development, community revenue sharing and small loan scheme as means of realising the development goal of the project.

Since the study sought to explore the impact of the ACID project from the perspectives and interpretations of the residents, a qualitative approach was adopted. As argued by Peterson (1994), one major purpose of qualitative research is to explore the full range of views on a certain subject and to develop the range of issues to be investigated in future research. Three out of the six project communities were selected for the study i.e. Beyin, Nzulezo and Ebonloa (Figure 2). 


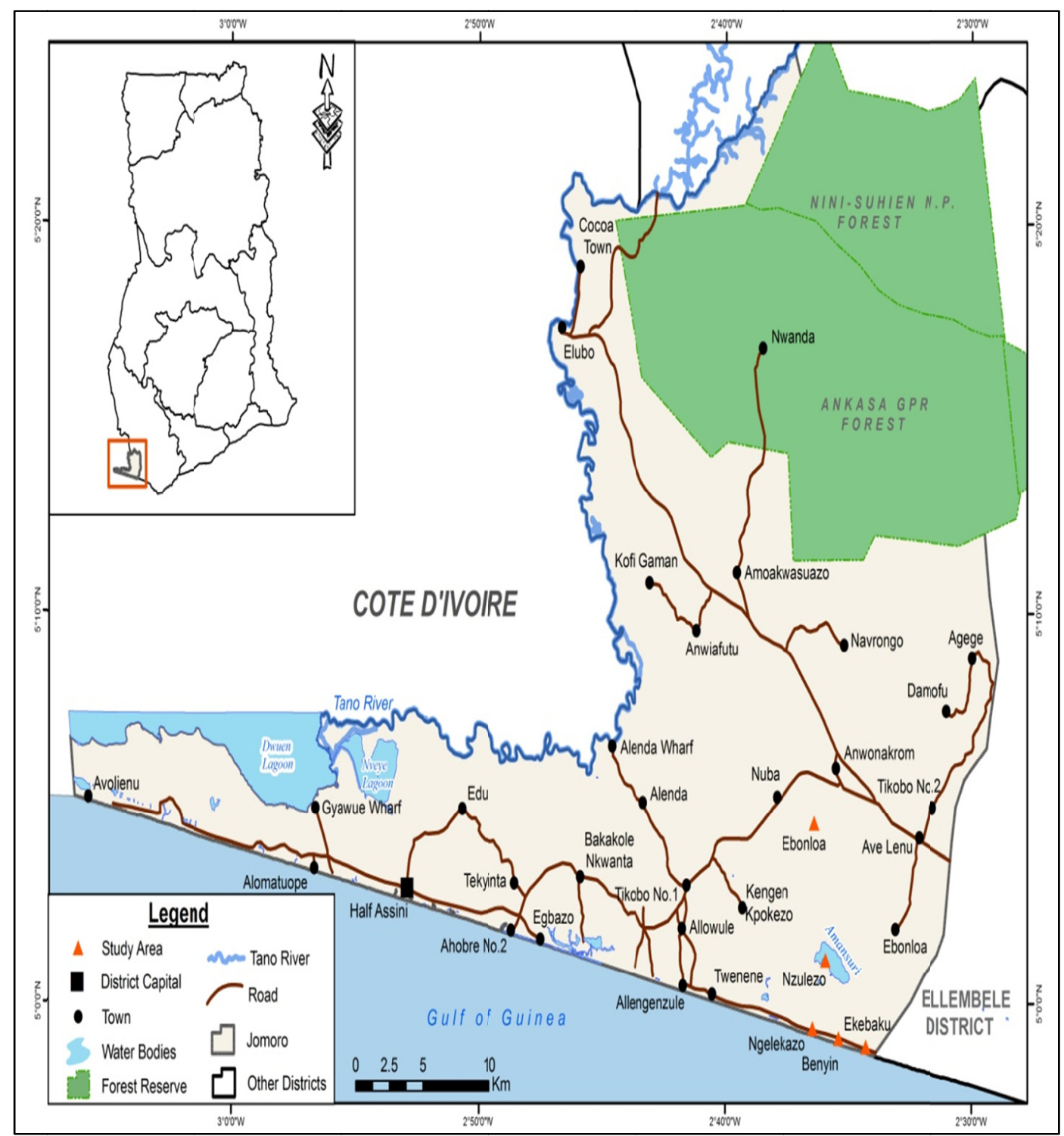

Figure 2. Study areas in regional and national context

Data for the study was collected in the months of March and April 2007. Four categories of respondents were chosen, namely: local residents, opinion leaders in the communities, local residents employed by ACID and project management. One hundred and ten (110) local residents aged 25 to 55 years (54 males and 56 females) participated in 12 focus group discussions (FGDs). Four (4) FGDs were conducted in each of the three communities with 8-12 participants in each session. The purpose of the FGD was to extract first hand indigenous knowledge relevant to the study, which might be less accessible using other research methods (Weeden, 2005). Each of the FGDs lasted approximately two hours.

In-depth, face-to-face interviews were also conducted, involving seven (7) opinion leaders, three (3) project managers, and ten (10) indigenes employed by the project to investigate their perspectives on the impact of the project. Convenience sampling technique was employed to select the ten (10) employees. Employees who report to work between the hours of $8 \mathrm{am}$ and $5 \mathrm{pm}$ were interviewed. After the tenth $\left(10^{\text {th }}\right)$ employee interview, it was concluded that new issues and themes were not likely to emerge from further interviews, hence the interviews with employees were considered to have reached saturation point. Kumar (2005) opines that this sampling procedure is acceptable in qualitative research. All the interviews and focus group sessions were recorded and transcribed in Microsoft Word format. The transcripts were then analysed and organised into thematic areas based on the five livelihood assets in the SLF. 


\section{Results}

\subsection{Direct Financial Benefits}

Employment of local residents constitutes a significant benefit of the project. Out of 20 people employed by the project, 18 were local residents. In addition, the project provides opportunity for engagement of local residents as casual labour. Besides working for the project, most of the local employees were engaged in multiple livelihood activities such as farming, coconut retailing, selling of fish, operation of drinking bars and management of home-stay schemes because of the flexibility associated with their employment. Income is spent on hospital bills, payment of children's school fees, remittances, funeral donations, food and clothing, among others. All the local residents employed by the project had between 2 and 5 dependents.

\subsection{Indirect Employment and Income}

Home-stay facilities (an accommodation service constructed with local materials and, in most cases, not more than five rooms owned and managed by local residents) have been established by local residents to meet the accommodation needs of tourists. Six of such facilities have been established in the communities and engage 16 local residents as casual workers to wash and cook for tourists, for a fee. Operators of the home-stay facilities also derive income from their activities. For instance, in 2005 alone, it was estimated that three home stay facilities collectively generated a gross income of $\mathrm{GH} \notin 3,500$.

It also emerged that drinking spot (local wine bar) businesses in the communities have expanded fairly. In Beyin, for example, the number of drinking bars increased from two (2) in the year 2000 to eight (8) in 2007. In the case of Nzulezo, there were no drinking spots at the onset of the project in 2000 but in 2007, the community boasted of four drinking spots. Three (3) drinking spots in Beyin reported a total profit of GH $\$ 965.70$ in 2006. The respondents further intimated that food vendors also benefited from the ecotourism project because tourists patronise their food and therefore, increase their sales, which ultimately, has enhanced their livelihood.

\subsection{Community Revenue Benefits}

A remarkable financial achievement of the project was the sharing of revenue generated from fees paid by tourists visiting the stilt village of Nzulezo among the communities. The accumulated fees are shared, annually, among six (6) communities (Nzulezo, Beyin, Ngelekazo, Ekabaku, Ebonloa, and Miegyinla) and other four (4) stakeholders based on an agreed sharing mechanism. Out of the 10 recipients of ecotourism revenue, the core fund receives the greater share $(20 \%)$. The core fund is a reserved account established for the purposes of meeting the operating cost of ACID at the end of the project life cycle. Collectively, the six communities receive less than half of total revenue disbursement (46\%) with Nzulezo and Beyin allocated 12 per cent and ten (10) per cent respectively, whilst the remaining four communities are allocated 8 percent each. The other stakeholders namely, the Western Nzema Traditional Council (19\%), the Stool Lands (10\%), and the Jomoro District Assembly (5\%) receive 34 per cent. At the same time, the communities borrow from the fund, using their share of ecotourism revenue as collateral.

Table 1. Revenue $(\mathrm{GH} \not / 0.95=\$ 1)$ distributed to Stakeholders from 2001 to 2006

\begin{tabular}{llllllll}
\hline Stakeholder & $\mathbf{2 0 0 1}$ & $\mathbf{2 0 0 2}$ & $\mathbf{2 0 0 3}$ & $\mathbf{2 0 0 4}$ & $\mathbf{2 0 0 5}$ & $\mathbf{2 0 0 6}$ & Total \\
\hline Beyin & $1,916.68$ & $2,769.79$ & 400.66 & 547.41 & 520.57 & 755.34 & $6,910.45$ \\
Nzulezo & $2,129.65$ & $3,385.30$ & 400.66 & 547.41 & 624.68 & 906.40 & $7,994.10$ \\
Ngelekazo & - & - & 400.66 & 547.41 & 416.45 & 604.27 & $1,968.79$ \\
Ekabaku & - & - & 400.66 & 547.41 & 416.45 & 604.27 & $1,968.79$ \\
Ebonloa & - & - & 400.66 & 547.41 & 416.45 & 604.27 & $1,968.79$ \\
Miegyinla & - & - & 400.66 & 547.41 & - & - & 948.07 \\
Stool Lands & - & - & 400.66 & 547.41 & 520.57 & 755.34 & $2,223.98$ \\
JDA & - & - & 200.33 & 273.70 & 260.28 & 377.67 & $1,111.98$ \\
WNTC & - & - & 200.33 & 273.70 & 789.08 & $1,435.14$ & $2,698.25$ \\
Core Fund & - & - & 801.32 & $1,094.82$ & $1,041.14$ & $1,510.68$ & $4,447.96$ \\
TOTAL & $4,046.33$ & $6,155.09$ & $4,006.60$ & $5,474.09$ & $5,005.67$ & $7,553.38$ & $32,241.16$
\end{tabular}

Source: ACID Visitor Data. GH $\not 0.95$ was exchanged for $\$ 1$ as of the time of data collection in 2007. 
As indicated in Table 1, from 2001 to 2006, beneficiaries of the ACID project received a total of GH $₫ 32,241.16$. Out of this amount, the six communities received GH\& 21, 758.99 (67\%). Nzulezo and Beyin had the greater share of the allocation to the communities GH $\phi 14,905.55$ or 68.5 per cent. These two communities are the highest recipients of ecotourism proceeds partly because they were the only beneficiaries in 2001 and 2002 and also because their percentage share is greater than the other communities (as shown in Figure 3) on account of their large share of the tourist traffic. In 2005, Miegyinla was expunged from the beneficiary communities for not contributing land towards the creation of the Amansure Community Nature Reserve.

\subsection{Utilisation of Community Revenue}

The study found that communities have used their share of revenue to execute a number of projects which are presented in Table 2.

Table 2. Project revenue usage by communities

\begin{tabular}{ll}
\hline Community & Project \\
\hline Nzulezo & - Extension of electricity to New Nzulezo; \\
& e Payment of salaries of four primary school; teachers \\
& employed by the community; \\
Ebonloa & - Construction of Chief's Palace. \\
& - Coctrification project in the community; \\
Beyin & - Maintenance of street lights; \\
& - Renovation of school buildings (Primary and JSS \\
& blocks); \\
& - Organisation of Annual Kudum Festival; \\
& Celebrations. \\
\hline
\end{tabular}

Source: Fieldwork, 2007.

Prior to the commencement of the ACID project, local residents of all the 52 communities under the Western Nzema Traditional Area were levied towards the celebration of the annual Kundum festival. However, since Beyin started receiving ecotourism funds, local residents were no longer levied for that purpose since ecotourism revenue is used to organise the Kundum festival in the common interest of all the communities concerned.

\subsection{Small Scale Enterprises Development Support Fund}

The ACID project established a Small Scale Enterprises Development Support Fund to provide financial and non-financial support to local residents to pursue alternative livelihood activities that will cause minimal impact on the natural resources of the area. All the research participants considered the disbursement of loans to local residents as a positive attribute of the project. The fund has since September 2003 disbursed GH $\not 16,8299.80$ to 74 local residents (Table 3). Beneficiaries were expected to repay the loans within three years, at 10 per cent interest.

Table 3. Loans disbursed to beneficiaries by community

\begin{tabular}{lll}
\hline Community & No. of beneficiaries & Amount granted \\
\hline Nzulezo & 15 & $\mathrm{GH} \phi 2,145$ \\
Ebonloa & 36 & $\mathrm{GH} \phi 10,066.80$ \\
Beyin & 23 & $\mathrm{GH} \phi 4,618$ \\
Total & $\mathbf{7 4}$ & $\mathbf{c 1 6 , 8 2 9 . 8}$ \\
\hline
\end{tabular}

Source: Fieldwork, 2007. 
Most of the respondents asserted that the small-scale loan scheme has brought tremendous opportunities to the beneficiaries. This was confirmed by some of the loan beneficiaries who indicated that their start-up capital had increased significantly. Some of the compliments made in support of this assertion were:

Initially, I only had GHф120 for my coconut oil processing; however, after receiving the loan my capital now stands at GHф350.

(Resident of Ebonloa Community)

People now have capital to start a business; previously most women in our communities were not working but because of the small-scale enterprise loan scheme, people have opened stores in the communities.

(FGD Participant)

People are now conveying coconut and coconut oil to Techiman and Accra, for sale, all because of the help from the small-scale enterprise loan granted by the project.

(Tour Guide)

Interestingly, however, some of the beneficiaries intimated that the loan did not help them. According to this category of beneficiaries, they have become indebted to the ACID project because they were unable to repay the loans. They attributed their inability to repay the loans to business failure as well as inadequacy of the loan granted them to meet operational cost of their business.

\subsection{Impact on Natural Asset}

On respondents' views on the project impact on natural asset, it was almost unanimously claimed that the wild animal populations in the natural environment of the project communities had increased, especially monkeys and bush pigs. This assertion is premised on the growing frequency of reported sightings of these animals in different locations. An 83,000 hectare community nature reserve designated as Amansuri Community Nature Reserve (ACNR) is a verifiable outcome of the project. This nature reserve is protected by the ACNR and the Wetland Ecosystem Bye-Law passed by the Jomoro District Assembly [under Section 52 of the Local Government Act 359 of 1971].

The research participants also contended that sanitation conditions in the communities had improved remarkably since the commencement of the project, with particular reference to the beach. One resident intimated:

I was personally using the beach as a place of convenience but now I have stopped this practice

(A resident of Beyin)

The participants attributed the improved sanitary conditions in the communities to the provision of refuse collection. The improvement in sanitation notwithstanding, it was unanimously alleged that some tourists litter the communities. Furthermore, it was revealed that sanitary conditions in Nzulezo have deteriorated due to improper disposal of household waste and complexities resulting from the location of the community.

Participants felt that there has been much improvement in the way and manner local residents use their natural assets. Improvement has been observed in the following areas:

- Reduction in the hunting of wild animals for bushmeat (e.g. sea turtles, birds, bush pigs);

- Reduced harvesting of trees in the wetland on commercial basis;

- Farming activities no longer take place in the wetland;

- Rare burning of charcoal in the communities; and,

- Defecating on the beaches is no longer the norm.

These changes were attributed to the conservation education by the ACID project in the communities; institution of bye-laws on the use of natural assets in the communities; enforcement of the bye-laws by the traditional authorities in the various communities; and, increased level of environmental awareness among local residents.

On accessibility to natural assets, some participants noted that their rights to natural assets have been curtailed since the commencement of the ACID project. For example, they no longer have access to bushmeat and sea turtles because hunting has been outlawed in the communities. When probed further, some local residents said they would kill animals whenever they had the opportunity. This discordant view was mostly among local residents who had not benefited directly from the project.

On the other hand, some other local residents were of the view that accessibility to natural resources had not been completely difficult to have, rather its use is being regulated for the common good. To reinforce this 
perception, they asserted that cutting down of trees for building purposes, for example, was allowed. In addition, alcohol distillation, which is a common occupation of the local residents of Nzulezo, was permitted at designated places within the wetland. Though the respondents conceded that some form of restrictions had been placed on charcoal burning, commercial logging, hunting and farming in the wetland, they perceived the restrictions to be in the interest of local residents. In their view, they would, in turn, benefit by means of ecotourism. These differences in opinion notwithstanding, local residents concluded that the impact of ACID on their natural asset had been, overall, positive.

\subsection{Impact on Social Assets}

Results from interviews and the FGDs indicate both negative and positive impacts of ACID on social assets of residents. For example, relationships among local residents are mixed, following the implementation of the ACID project. There are indications of community cohesion and unity of purpose among local residents. This could be deduced during community meetings organised to deliberate on the utilisation of community revenue. In addition, residents collectively share the pride and happiness resulting from the growing image of the ACID project as a principal ecotourism destination in the Western Region, and this has enhanced community cohesion, cordiality, and reciprocal relationship among loan beneficiaries.

The disbursement of the Small Scale Enterprises Support Fund loans through cooperative societies formed within the communities has also promoted mutual support, among local residents. It was found that members of these associations pay dues and meet regularly in their communities. Though the aim of these associations was to facilitate accessibility to the small-scale loans, members assist each other by means of donations in times of bereavement, marriage, naming ceremonies and other social engagements. Voluntary social support systems have, therefore, been introduced into the associations. The sad reality is that most of the associations ceased to function immediately after the disbursement of the loans. In other words, it appears the positive dimensions of social capital could not be sustained.

Indications of community cohesion notwithstanding, there were strong signs of division among local residents. Indeed, they appear to be divided between loan beneficiaries and non-beneficiaries. Local residents who have not received loans from the Small Scale Enterprises Development Support Fund appeared aggrieved and their failure to obtain loans from the fund seemed to influence their negative attitude and impressions about the ACID project. A fisherman from a society that had not benefited from the scheme summed up his feelings as follows:

The ACID project advised us to form a cooperative society as a condition for us to benefit from the loan scheme. However, none of our members, to date, has received a loan. As a result, our society has collapsed.

Some of the non-beneficiaries threatened to resume hunting of animals from the wetland because, according to them, they had no alternative source of livelihood. For example, a resident from Ebonloa said:

I stopped hunting bush pigs because I thought I would also benefit from the loan to enable me to engage in trading. However, up to date, I have not been given the money and I have no option but to go back to hunting. One bush pig can fetch me nearly GHф60.

\subsection{Impact on Public Physical Assets}

It is clear from the study that there has been a change in the physical assets of local residents in the communities (Table 4).

Table 4. Direct and indirect impact of ACID on physical assets of residents

\begin{tabular}{|c|c|}
\hline Direct & Indirect \\
\hline - $\quad$ Construction of walkway in Nzulezo & $\begin{array}{l}\text { - Extension of electricity to Ekabaku, } \\
\text { New Nzulezo and Ebonloa }\end{array}$ \\
\hline $\begin{array}{l}\text { - Construction of a canal linking Beyin } \\
\text { and Nzulezo }\end{array}$ & - $\quad$ Construction of school building \\
\hline \multirow[t]{2}{*}{$\begin{array}{l}\text { - Provision of visitor reception centre at } \\
\text { Beyin }\end{array}$} & - Maintenance of local market in Beyin \\
\hline & $\begin{array}{l}-\quad \text { Provision of mobile telephone facility } \\
\text { (MTN and One-Touch) }\end{array}$ \\
\hline
\end{tabular}

Source: Fieldwork, 2007. 
As reported in Table 4, a 312-meter walkway (streets and alleys) in Nzulezo has been reconstructed by the project. The walkway is a raised platform that facilitates the movement of residents and visitors to Nzulezo. Residents of Beyin and Nzulezo felt that the construction of a canal is one of the direct additions to the physical assets of their communities. The purpose of the canal was to ease transportation between Nzulezo and the surrounding communities, which becomes extremely difficult during the dry season when the water level in the lagoon recedes drastically to the extent that transportation by dugout canoe becomes laborious. Nevertheless, a majority of the local residents pointed out that the construction of the canal has not eased transportation between Nzulezo and the main-land as expected. Rather, during the dry season, the canal is not usable because of low water level, and commuters and tourists continue to walk for over 30 minutes before boarding the canoes to Nzulezo. The construction of a visitor reception facility at Beyin by the ACID project was also mentioned as a direct result of the project. The facility, which is made of three offices, a conference room and washrooms, serves as the secretariat of ACID.

Furthermore, it became known that mobile telephone providers i.e. MTN (formerly Scancom Ghana Limited) and Ghana Telecom (now Vodafone) have extended their services to the communities. This, the local residents attributed to the growing popularity of the area as a major ecotourism destination in the country. It was claimed that the project formally requested the extension of telephone services to the area in order to meet the communication needs of tourists. It is, however, difficult to attribute the extension of telephone services to the area by the two companies to the ACID project. This is because of the nationwide expansion drive by the two companies to be competitive. Nevertheless, the facilitating role of ACID cannot be overlooked.

\subsection{Impact on Human Assets}

Local residents employed by the project have benefited from on-the-job training programmes organised under the ACID project. For instance, in 2001, tour guides were trained in communication skills, tour guiding, hygiene, forest protection, first aid and interpretative services. Selected teachers in the communities, tour guides and community agents have been trained in snail and grasscutter rearing as well as leafy vegetable farming. Additionally, in connection with the operation of the Small Scale Enterprises Development Support Fund, petty traders, chop bar operators and farmers in the project communities have also been trained in simple accounting and record keeping, business creation and improvement. Another significant indirect impact of the ACID project on the human capital of the communities is the use of income by local residents employed by the project to educate their children. Moreover, these local residents use their income for medical expenses on themselves and families. These expenses go a long way to improve the quality of human capital of the communities. Similarly, the construction of school buildings and payment of salaries of teachers help to expand the human capital-base of the local residents through enhancement in the knowledge and skills of the people in the long term.

\section{Conclusion}

The study revealed that the ACID project has impacted on the livelihood assets of the local residents of Beyin, Nzulezo and Ebonloa. Tourism and hospitality employment opportunities have been created in the communities. Nonetheless, employment opportunities were found to be limited to only a few residents. This finding is similar to the conclusion of Barrow et al. (2000) that few jobs are created by community wildlife projects. Given the small size of the project, it is clear that the ACID project could not have engaged more than it currently does. Some residents have experienced increase in household incomes due to ACID project employment, while casual employment avenues and ecotourism-related businesses have resulted from the project. Through the Small Scale Enterprises Development Support Fund, some residents were able to access credit facilities for business purposes and this ensured that more local residents had direct financial benefit from the project. The extent to which the loan led to increment in household income could not be determined because it fell outside the ambit of the current study.

Unlike some CBNRM projects where revenue is disbursed on household basis, in the ACID project the income from ecotourism is allocated to communities. This flexibility in decision-making regarding revenue distribution and utilisation is a major feature of community-managed protected areas. At the moment this is not the case with government-managed protected areas in the country.

It is clear from the study that communities appreciate the conservation efforts of the ACID project and felt that the impact of the project on natural assets of the communities has been positive. Interestingly, the appreciation of natural assets being demonstrated by the residents is conditional as far as the ACID project stimulates development in a community then conservation of natural resources is acceptable to residents. On the other hand, conservation without development was unsatisfactory. This finding confirms the conclusion of Turner (2004) 
that local communities do not value conservation in itself and therefore, community participation in natural resource management without development will jeopardize conservation objectives.

Physical assets in the communities have seen some transformation and this change is attributable to the project. The provision of electricity and school buildings through project revenue is a case in point. Indirectly, the extension of mobile telephone services to the communities is also as a result of the growing reputation of the project area as an important ecotourism site in the country.

However, the conclusions have been reached mindful of possible limitations of the study. First, by the design of the study, establishing causality becomes difficult. For instance, the alterations that have occurred to the livelihood assets of the communities could have happened naturally or due to other factors unrelated to the ACID project. Secondly, the study did not pursue quantitative probing into the contribution of ACID to household income of local residents, especially beneficiaries of the loan scheme, employees, food vendors and operators of accommodation facilities and drinking bars. Thirdly, the purposive sampling used in the selection of participants has the potential of introducing bias. The involvement of different categories of participants was undertaken purposely to reduce the impact of bias on the findings of the study. In the area of research, there is the need to conduct a quantitative study to establish the impact of the project on the livelihood of community members. It is also important to study the Small Scale Enterprises Development Fund (SSEDF) to uncover issues relating to its contribution to household incomes of beneficiaries.

\section{References}

Adato, M., \& Meinzen-Dick, R. (2002). Assessing the Impact of Agricultural Research on Poverty Using the Sustainable Livelihoods Framework. Food Consumption and Nutrition Division (FCND) discussion paper 128/ Environment and Production Technology Division (EPTD) discussion paper 89. Washington D.C. International Food Policy Research Institute.

Arntzen, J. W., Molokomme, D. L., Terry, E. M., Moleele, N., Tshosa, O., \& Mazambani, D. (2003). Final Report of the Review of Community-Based Natural Resource Management in Botswana. Report prepared by the Centre for Applied Research for the National CBNRM Forum. Gaborone.

Ashley, C. (1999). Financial and Livelihood Impacts of butterfly farming at Arabuko Sokoke Forest. Kenya. African Wildlife Foundation.

Bandyopadhyay, S., Humavindu, M. N., Shyamsundar, P., \& Wang, L. (2004). Do Households Gain from Community-based Natural Resource Management? An Evaluation of Community Conservancies in Namibia. Working Paper 3337. Washington D. C. World Bank.

Barrow, E., \& Fabricius, C. (2002). Do rural people really benefit from protected areas-rhetoric or reality? Parks, 12(2), 67-79.

Barrow, E., Gichohi, H., \& Infield, M. (2000). Rhetoric or Reality? A Review of Community Conservation Policy and Practice in East Africa. London: International Institute for Environment and Development.

Bond, I., \& Frost, G. H. (2005). CAMPFIRE and the Payment for Environmental Services. Paper prepared for the workshop: Payments for Environmental Services (PES)-Methods and Design in Developed and Developing countries. Titisee, Germany, $15^{\text {th }}-18^{\text {th }} 2005$.

Bruner, A. G., Gullison, R. E., Rice, R. E., \& Da Fonseca, G. A. B. (2001). Effectiveness of Parks in Protecting Tropical Biodiversity. Science, 291, 125-128. http://dx.doi.org/10.1126/science.291.5501.125

Department for International Development. (1999). Sustainable livelihoods Guidance Sheets. London: DFID.

Elasha, B. O., Elhassan, G. N., Ahmed, H., \& Zakielden, S. (2005). Sustainable Livelihood approach for assessing community resilience to climate change: case studies from Sudan. Assessments of Impacts and Adaptations to Climate Change (AIACC) Working Paper No. 17.

Ghana Wildlife Society (GWS). (1998). Project Proposal. Amansuri Conservation and Integrated Development project. Accra: Ghana Wildlife Society.

Gubbi, S., Linkie, M., \& Leader-Williams, N. (2009). Evaluating the legacy of an integrated conservation and development project around a tiger reserve in India. Environmental Conservation, 35(4), 331-339. http://dx.doi.org/10.1017/S0376892908005225

Hughes, R., \& Flintan, F. (2001) Integrating Conservation and Development Experience: A Review and Bibliography of the ICDP Literature. London: International Institute for Environment and Development.

Jeanrenaud, S. (2002). People-Oriented Approaches in Global Conservation: Is the Leopard Changing its Spots? 
London: International Institute for Environment and Development (IIED) and Institute for Development Studies (IDS).

Kijazi, A. J. H. (1996). Multiple Land Use Protected Areas: Experience from the Ngorongoro Conservation Area. Paper presented at the Pan African Symposium on Sustainable Use of Renewable Natural Resources and Community Participation, Harare, 24-27 June 1996.

Koziell, I., \& Inoue, C. Y. A. (2006). Mamirauá Sustainable Development Reserve,Brazil: Lessons Learnt In Integrating Conservation With Poverty Reduction. Biodiversity and Livelihoods Issues No.7 International Institute for Environment and Development (IIED). London.

Kumar, C. (2005). Revisiting 'community' in community-based natural resource management. Community Development Journal, 40(3), 275-285. http://dx.doi.org/10.1093/cdj/bsi036

Larson, P. S., Freudenberger, M., \& Wyckoff-Baird, B. (1998). WWF Integrated Conservation and Development Projects: Ten Lessons from the Field 1985-1996. Washington D.C.

Li, T. M. (2002). Engaging Simplifications: community-based resource management, market process and state agends in upland Southeast Asia. World Development, 30(2), 265-283. http://dx.doi.org/10.1016/S0305-750X(01)00103-6

Long, S. A. (2004). Livelihoods and CBNRM in Namibia: The Findings of the WILD Project, Final Technical Report of the Wildlife Integration for Livelihood Diversification Project (WILD), prepared for the Directorates of Environmental Affairs and Parks and Wildlife Management, the Ministry of Environment and Tourism, the Government of the Republic of Namibia. Windhoek.

Madden, F. (2006). Gorillas in the garden-Human-wildlife conflict at Bwindi Impenetrable National Park. Policy Matters, 14, 180-190.

Newman, K., \& Webster, J. (1993). African biodiversity: Foundation for the Future. A framework for integrating biodiversity conservation and sustainable development. Biodiversity Support Program. Gland, Switzerland: World Wildlife Fund.

Newmark, W. D., \& Hough, J. L. (2000). Integrated Conservation and Development Projects and Beyond. BioScience, 50(7), 585-592. http://dx.doi.org/10.1641/0006-3568(2000)050[0585:CWIAIC]2.0.CO;2

Nhantumbo, I., Norfolk, S., \& Pereira, J. (2003). Community based natural resources management in Mozambique: a theoretical or practical strategy for local sustainable development? The case study of Derre Forest Reserve. Sustainable Livelihoods in Southern Africa Research Paper 10, Brighton Institute of Development Studies.

Nkhata, B., \& Breen, C. M. (2010). Performance of community-based natural resource governance for the Kafue $\begin{array}{llll}\text { Flats (Zambia). } & \text { Environmental 296-302. }\end{array}$ http://dx.doi.org/10.1017/S0376892910000585

Peterson, R. A. (1994). A Meta-analysis of Cronbach's Coefficient Alpha. Journal of Consumer Research, 21(September), 381-391. http://dx.doi.org/10.1086/209405

Shen, F., Hughey, K. F. D., \& Simmons, D. G. (2008). Connecting the Sustainable Livelihoods Approach and Tourism: A Review of the Literature. Journal of Hospitality and Tourism Management, 15, 19-31. http://dx.doi.org/10.1375/jhtm.15.1.19

Turner, R. L. (2004). Communities, wildlife conservation, and tourism-based development: can community-based nature tourism live up to its promise? Journal of International Wildlife Law \& Policy, 7(i3-4), 161(22).

World Bank. (1995). West Africa Pilot Community Based Natural Resource and Wildlife Management Project (GEPRENAF). Staff Appraisal Report. Washington, D.C. 